\title{
Simultaneous removal of organic carbon and nitrogen pollutants in the Yangtze estuarine sediment: The role of heterotrophic nitrifiers
}

\author{
Qiang Jin ${ }^{\mathrm{a}}$, Jian $\mathrm{Lu}^{\mathrm{b}, *}$, Jun $\mathrm{Wu}^{\mathrm{c}, * *}$, Yongming Luo ${ }^{\mathrm{b}}$ \\ a School of Environmental Science and Engineering, Shanghai Jiao Tong University, Shanghai 200240, PR China \\ ${ }^{\mathrm{b}}$ Key Laboratory of Coastal Environmental Processes and Ecological Remediation, Yantai Institute of Coastal Zone Research, Chinese Academy of Sciences, \\ Yantai, Shandong 264003, PR China \\ c Qinghai Institute of Salt Lakes, Chinese Academy of Sciences, Xining, Qinghai 810008, PR China
}

\section{A R T I C L E I N F O}

\section{Article history:}

Received 20 May 2016

Received in revised form

19 December 2016

Accepted 16 April 2017

Available online 18 April 2017

\section{Keywords:}

Sediment

Estuary

Nitrification

Functional redundancy

\begin{abstract}
A B S T R A C T
The Yangtze Estuary is one of the most eutrophic coastal areas in the world. The engagement of heterotrophic nitrification bacteria in the simultaneous removal of organic carbon and ammonium in the Yangtze estuarine sediment was investigated. The specific nitrification rate in the selective autotrophic nitrification inhibition treatment was about $25 \%$ of that in the control without autotrophic nitrification inhibition, suggesting that heterotrophic nitrification, in addition to autotrophic nitrification, was an important nitrification process in the sediment. The increase of heterotrophic nitrification can offset the decrease in autotrophic nitrification, which subsequently leads to the high tolerance of nitrification to the organic carbon. The number of heterotrophic nitrification bacteria was $7.1 \times 10^{7} \mathrm{MPN} \mathrm{g}^{-1}$ in sediment collected from Site 1 while that of autotrophic nitrification bacteria was $4.2 \times 10^{8} \mathrm{MPN} \mathrm{g}^{-1}$. The isolation of heterotrophic nitrification bacteria provides direct evidence of the engagement of heterotrophs in the nitrification of the Yangtze estuarine sediment. The results show that nitrification is catalyzed by both the autotrophs and the heterotrophs, indicating functional redundancy of nitrification in sediment. Since organic carbon usually coexists with ammonium, these findings indicate an alternative bioprocess for the simultaneous removal of organic carbon and ammonium in Yangtze estuarine sediment.
\end{abstract}

(๔) 2017 Elsevier Ltd. All rights reserved.

\section{Introduction}

Ammonium can cause increased oxygen demand and eutrophication in rivers and lakes, which makes it an important contaminant in various environments (Rittmann and McCarty, 2001). As the biological oxidation of ammonium to nitrite and nitrate, nitrification has been proven to be an effective method for ammonium removal (Rittmann and McCarty, 2001). In most cases, ammonium often coexists with organic contaminants. However, nitrification is the most sensitive part in the biological nutrient removal process, with the autotrophic nitrifying biomass being approximately $10 x$ more sensitive to organic contaminants than its aerobic heterotrophic counterpart (Juliastuti et al., 2003). Nitrification may be severely inhibited by these coexisting organic contaminants since the nitrification process is catalyzed by autotrophic

\footnotetext{
* Corresponding author.

** Corresponding author.

E-mail address: jlu@yic.ac.cn (J. Lu).
}

bacteria (Strauss and Lamberti, 2000). A previous study showed that ammonia oxidation could be totally inhibited by glucose (>30 $\mathrm{mg} \mathrm{C} \mathrm{L}^{-1}$ ) in aquatic sediments (Strauss and Lamberti, 2000).

Nitrification is generally thought to be performed by a suite of autotrophic bacteria including Nitrosomonas, Nitrosovibrio, Nitrosolobus, Nitrosospira, and Nitrobacter (Rittmann and McCarty, 2001). The most commonly recognized ammonium-oxidizing nitrifiers are Nitrosomonas, Nitrosovibrio, Nitrosolobus, and Nitrosospira (Bernhard and Bollmann, 2010; Elizondo-Patrone et al., 2015; Vetterli et al., 2015). Although these bacteria can also further oxidize nitrite into nitrate, Nitrobacter is the most widely known genus of the nitrite oxidizers. Being autotrophs, these nitrifiers are obligate chemolithotrophs that obtain energy from oxidation of ammonia (Bock et al., 1986). In addition to autotrophic nitrifers, heterotrophic microorganisms may also perform nitrification (Schimel et al., 1984; Pedersen et al., 1999; Kim et al., 2005). Bacteria capable of heterotrophic nitrification have been studied as potential microorganisms that may be used to overcome problems inherent in conventional methods (Joo et al., 2005). Previous studies have directly addressed the relative importance of 
autotrophic and heterotrophic nitrification in soil (Schimel et al., 1984; Pedersen et al., 1999). Schimel et al. (1984) showed that the potential for heterotrophic nitrification in forest soil was greater than that for autotrophic nitrification by adding acetylene as the specific inhibitor of autotrophic nitrification into the slurry. Acetylene is a well known inhibitor of nitrification that acts specifically on ammonium-oxidizers and does not inhibit heterotrophic nitrification processes (Hynes and Knowles, 1982; Schimel et al., 1984; Dore and Karl, 1996; Bateman and Baggs, 2005). Pedersen et al. (1999) found that heterotrophic nitrification was the dominant mode of nitrification in young and mature forested sites, while autotrophic nitrification was the most important mode in clear cut areas. Many studies have suggested that heterotrophic nitrification could be important in soil or sediment that contains plenty of organic carbon (Schimel et al., 1984; Miller and Cooney, 1994; Pedersen et al., 1999; Islam et al., 2007). Miller and Cooney (1994) evaluated the effect of butyltin on the heterotrophic nitrifying bacteria from surficial estuarine sediments. The Yangtze Estuary is one of the most eutrophic coastal areas in the world (Wang, 2006; Xu et al., 2013, 2015; Lin et al., 2016) but little information is available on the occurrence and importance of heterotrophic nitrification in the sediment in this area.

Bacterial heterotrophic nitrification has tended to be underestimated in many cases. A preliminary study showed that nitrification in aquaculture pond sediment, which could simultaneously remove organic substrate and ammonium, had high tolerance to organic carbon. The nitrification process was not significantly inhibited when the organic carbon loading was relatively high, which is beyond our expectation based on traditional nitrification theory. The current study examined the engagement of heterotrophic nitrification bacteria in the simultaneous removal of organic carbon and ammonium in the Yangtze estuarine sediment and evaluated the functional role of heterotrophic nitrifiers. The objective of this study was to obtain theoretical information on simultaneous removal of organic carbon and ammonium by heterotrophic nitrifying bacteria in the Yangtze estuarine sediment.

\section{Materials and methods}

\subsection{Chemicals, reagents, sediment and medium}

High-purity Milli-Q water was produced in a MilliQ Plus system (Millipore, USA). All other reagents obtained from Fisher Scientific (Pittsburgh, PA, USA) were of reagent grade. Sediment samples were collected near the southern side of Yangtze estuary in August, 2015 (Fig. 1), with the detailed location information of $\left(31^{\circ} 28^{\prime} \mathrm{N}\right.$, $\left.121^{\circ} 23^{\prime} \mathrm{E}\right)$ and $\left(31^{\circ} 17^{\prime} \mathrm{N}, 121^{\circ} 43^{\prime} \mathrm{E}\right)$ for $\mathrm{S}-1$ and $\mathrm{S}-2$, respectively. Surficial sediment samples were collected from the upper $10 \mathrm{~cm}$ of the sediment layer. Glass jars were filled with sediment, sealed, transported to the laboratory, and stored at $4{ }^{\circ} \mathrm{C}$ until used. The $\mathrm{pH}$ of the sediments samples ranged from 7.82 to 8.47 (Table 1). Concentrations of total organic carbon (TOC) ranged from 6.96 to $4.43 \mathrm{~g} \mathrm{~kg}^{-1}$ while those of total nitrogen (TN) 5.77 to $3.37 \mathrm{~g} \mathrm{~kg}^{-1}$.

The basic composition of the medium used in the nitrification test was as follows: $\mathrm{MgCl}_{2} \cdot 6 \mathrm{H}_{2} \mathrm{O}\left(0.1 \mathrm{~g} \mathrm{~L}^{-1}\right), \mathrm{CaCl}_{2}\left(0.1 \mathrm{~g} \mathrm{~L}^{-1}\right)$, $\mathrm{FeCl}_{2} \cdot 4 \mathrm{H}_{2} \mathrm{O}\left(0.01 \mathrm{~g} \mathrm{~L}^{-1}\right), \mathrm{K}_{2} \mathrm{HPO}_{4}\left(0.27 \mathrm{~g} \mathrm{~L}^{-1}\right), \mathrm{KH}_{2} \mathrm{PO}_{4}\left(0.35 \mathrm{~g} \mathrm{~L}^{-1}\right)$, $\mathrm{NaHCO}_{3}\left(2.5 \mathrm{~g} \mathrm{~L}^{-1}\right)$. Organic carbon (glucose) and ammonium $\left(\mathrm{NH}_{4} \mathrm{Cl}\right)$ added into the medium to investigate the nitrification and organic carbon removal. Trace salts were also amended into the medium according to Somsamak et al. (2001) and the pH was adjusted to 7 using $1 \mathrm{M} \mathrm{HCl}$.

\subsection{Sediment-slurry incubation experiment}

To investigate the simultaneous removal of organic carbon and ammonium in the sediment, initial concentrations of ammonium- $\mathrm{N}$ in all treatments were $40 \mathrm{mg} \mathrm{L}^{-1}$ while those of the total organic carbon (TOC) were $80 \mathrm{mg} \mathrm{L}^{-1}$. Sediment was centrifuged at $4000 \mathrm{rpm}$ for $10 \mathrm{~min}$, washed twice with nitrification medium, and suspended in the same medium at approximately $10.0 \mathrm{~g} \mathrm{~L}^{-1}$ of MLSS (mixed liquid suspended solid). Incubations were conducted in $1 \mathrm{~L}$ serum bottles sealed with rubber septa. The incubation $(100 \mathrm{~mL})$ was flushed with high purity oxygen for about $15 \mathrm{~min}$ and the head space of the bottles was oxygen. Incubations were performed at $25^{\circ} \mathrm{C}$ and $120 \mathrm{rpm}$ in darkness. The assay was completed within a short period $(6 \mathrm{~h})$ to avoid the disturbance of nitrogen anabolism due to the growth and reproduction of bacteria. Samples were collected after the treatment for the analysis. All experiments were performed in triplicate. Sterile controls were autoclaved three times on consecutive days before the biodegradation test. A control without organic carbon was also included. Samples were collected after the treatment for the analysis.

To determine the occurrence of heterotrophic nitrification, a specific inhibitor for autotrophic nitrification (acetylene) (Hynes and Knowles, 1982; Schimel et al., 1984; Dore and Karl, 1996; Bateman and Baggs, 2005) was injected into the incubation systems at a concentration of $0.01 \%(v / v)$ following Bateman and Baggs (2005). At the end of the experiment, samples collected from treatments without autotrophic nitrification inhibitor were used for determining the specific nitrification rate; while samples from all the treatments in which the autotrophic nitrification was totally inhibited using selective autotrophic nitrification inhibitor were used to determine the specific heterotrophic nitrification rate. The specific autotrophic nitrification rate was determined using the specific nitrification rate minus the specific heterotrophic nitrification rate.

To investigate the effect of organic carbon concentration on the heterotrophic and autotrophic nitrification, organic carbon (glucose) $\left(40,80,120\right.$, and $160 \mathrm{mg}$ TOC $\left.\mathrm{L}^{-1}\right)$ was added into the inorganic media to simulate different organic loadings. A control without organic carbon was also included. Initial concentration of ammonium $\mathrm{N}$ was $40 \mathrm{mg} \mathrm{L}^{-1}$.

\subsection{Enumeration of heterotrophic and autotrophic bacteria in the sediment}

Nitrification bacteria enumeration was performed according to Papen and von Berg (1998) with slightly modification. The sediment was mixed in $100 \mathrm{~mL}$ sterile $0.9 \%$ sodium-chloride solution at $10.0 \mathrm{~g} \mathrm{~L}^{-1}$ of MLSS. The suspension was shaken for $30 \mathrm{~min}$ on a rotary shaker $(130 \mathrm{rpm})$ at room temperature $\left(20^{\circ} \mathrm{C}\right)$ for desorption of bacterial cells. The suspension was allowed to settle for $1 \mathrm{~min}$, before the supernatant containing the desorbed bacterial cells was decanted into $300 \mathrm{~mL}$ sterile Erlenmeyer flasks. A series of $10^{-1}$ dilutions (highest dilution step: $10^{-11}$ ) was prepared from the supernatant. From each dilution step, 5 tubes containing $9 \mathrm{~mL}$ heterotrophic nitrification medium or autotrophic nitrification medium were each inoculated with $1 \mathrm{~mL}$ of the diluted supernatant. Heterotrophic nitrifiers were assayed by the Most Probable Number (MPN) method as previously described (Papen and von Berg, 1998). Autotrophic nitrifiers were assayed by the MPN method of Alexander and Clark (1965).

\subsection{Isolation of heterotrophic nitrifier and heterotrophic nitrification assay}

Heterotrophic nitrifiers were successively isolated from the sediment by plating onto a peptone-meat extract (PM) agar that was made according to Papen and von Berg (1998). The resulting isolates of bacteria were tested for their capability to produce 


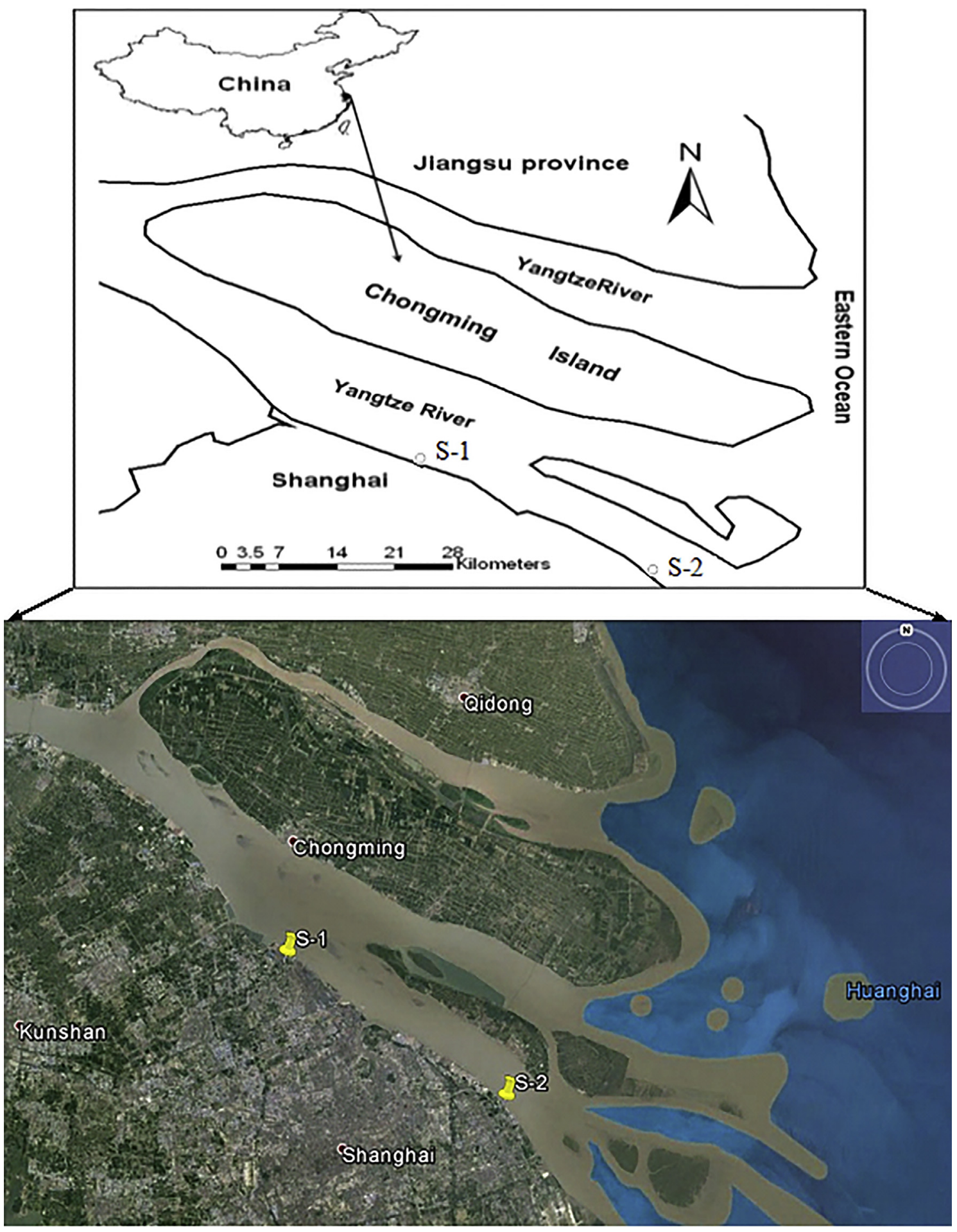

Fig. 1. Sediment sampling sites of the Yangtze River Estuary. Both Site 1 (S-1) and Site 2 (S-2) locate near the southern side of the Yangtze River Estuary.

Table 1

Physicochemical characteristics of the Yantze estuarine sediment.

\begin{tabular}{llll}
\hline Estuarine Sediment & $\mathrm{pH}$ & $\mathrm{TOC}\left(\mathrm{g} \mathrm{kg}^{-1}\right)$ & $\mathrm{TN}\left(\mathrm{g} \mathrm{kg}^{-1}\right)$ \\
\hline Site $1(\mathrm{~S}-1)$ & 7.82 & 6.96 & 5.77 \\
Site 2 (S-2) & 8.47 & 4.43 & 3.37 \\
\hline
\end{tabular}

nitrite or nitrate by inoculation into $10 \mathrm{~mL}$ sterile ammonium sulfate liquid medium. Spot tests for total oxidized-N (nitrite and nitrate) were carried out on approximately $2 \mathrm{~mL}$ medium using the Griess-Ilosvay method (Keeney and Nelson, 1982). When the test was positive, $2 \mathrm{~mL}$ of the enrichment cultures was transferred to PM agar for further purification. This procedure was repeated several times until the isolated strain was purified. The strains were freeze-dried and stored at $-80^{\circ} \mathrm{C}$ for future usage.

The freeze-dried strain was added to Luria-Bertani (LB) medium and cultivated at $30^{\circ} \mathrm{C}$ and $120 \mathrm{rpm}$ in darkness. After 7 days, the 
cells were harvested by centrifugation at $4000 \mathrm{rpm}$ for $10 \mathrm{~min}$ and washed twice with $20 \mathrm{mM}$ potassium phosphate buffer solution ( $\mathrm{pH}=7.0$ ) before being used for inoculation. For the heterotrophic nitrification test of isolated strains, the cells were suspended in the culture medium at $1.0 \mathrm{~g} \mathrm{~L}^{-1}$ dry weight. Ammonium-N was used as the nitrogen source. Glucose was added as a carbon source. Initial concentrations of ammonium-N and TOC (glucose) were $40 \mathrm{mg} \mathrm{L}^{-1}$ and $120 \mathrm{mg} \mathrm{L}^{-1}$, respectively. Incubations were performed in $500 \mathrm{~mL}$ flasks closed with cotton caps, each containing $100 \mathrm{~mL}$ culture medium. Incubations were performed at $25^{\circ} \mathrm{C}$ and $120 \mathrm{rpm}$ in darkness.

\subsection{Amplification of $16 \mathrm{~S}$ rDNA from isolated heterotrophic nitrifiers}

Cells of strain UT10 or YIC-JL1 cultured on LB medium were transferred to an Eppendorf tube containing $100 \mu \mathrm{L}$ aseptic doubledistilled water. The mixture was kept in boiling water for $5 \mathrm{~min}$ and then was centrifuged at $12,000 \mathrm{rpm}$ for $5 \mathrm{~min}$. The supernatant was directly used for amplification as template DNA. DNA fragment encoding 16S rRNA was amplified using the universal primer BSF8/ 20 and the reverse primer BSR154/20 (Devereux and Willis, 1995). The primer sequences were 5'-AGAGTTTGATCCTGGCTCAG-3' for BSF8/20, and 5'-AAGGAGGTGATCCAGCCGCA-3' for BSR154/20. PCR amplifications were performed with a Mastercycler gradient PCR system (Eppendorf China Ltd.). The PCR solution (50 $\mu \mathrm{L})$ consisted of $36.5 \mu \mathrm{L}$ of sterile water (Sangon, Shanghai, China), $10 \mu \mathrm{L}$ of $10 \times$ Taq buffer (Sangon, Shanghai, China), $4 \mu \mathrm{L} \mathrm{MgCl}_{2}$ solution (25 mM), $1 \mu \mathrm{L}$ of each primer $(20 \mu \mathrm{M}), 1 \mu \mathrm{L}$ of deoxynucleotide triphosphates mixture ( $10 \mathrm{mM}), 1 \mu \mathrm{L}$ of template DNA solution, and $0.5 \mu \mathrm{L}$ Taq polymerase ( $5 \mathrm{U} \cdot \mu \mathrm{L}^{-1}$, Sangon, Shanghai, China). The amplification reactions were performed at $94^{\circ} \mathrm{C}$ for $2 \mathrm{~min}$, followed by 29 cycles at $94{ }^{\circ} \mathrm{C}$ for $1 \mathrm{~min}$, at $58{ }^{\circ} \mathrm{C}$ for $1 \mathrm{~min}$, and at $72{ }^{\circ} \mathrm{C}$ for $2 \mathrm{~min}$, with a final extension at $72{ }^{\circ} \mathrm{C}$ for $10 \mathrm{~min}$. PCR products were verified by electrophoresis in a $0.8 \%$ agrose gel. Fragments were cut and purified using UNIQ-10 DNA purification kits (Sangon, Shanghai, China), and then sequenced commercially (Sangon, Shanghai, China) with an ABI 3730 DNA analyzer (Applied Biosystems) using the BSF8/20 primer.

\subsection{DNA sequence analysis}

The 16S r DNA sequences of other strains have high similarity with the isolated heterotrophic nitrifier (strain UT10 and YIC-JL1) obtained from the Genbank database (National Central for Biotechnology Information, NCBI) (Wheeler et al., 2001) using the BLAST search program (Altschul et al., 1997). To obtain the reference $16 S$ rDNA sequences of typical autotrophic nitrifiers, model autotrophic nitrification nitrifiers were selected according to Rittmann and McCarty (2001) and their 16S rDNA sequences were retrieved from GenBank database. The 16S rDNA sequences of heterotrophic nitrifiers were aligned with reference sequences obtained from the Genbank database using CLUSTAL W program (Thompson et al., 1997), and a phylogenetic tree was generated using the DNAMAN software 5.22 (Lynnon Biosoft, Quebec, Canada). The names of bacteria used for the phylogenetic analysis and their nucleotide sequence accession numbers were all shown in the constructed phylogenetic tree.

\subsection{Analytical methods}

Concentrations of TOC and TN were measured using an elementary analyzer following previous method (Hou et al., 2012; Lin et al., 2016). All water samples were centrifuged for $15 \mathrm{~min}$ at $12,000 \mathrm{rpm}$ before subsequent analysis. $\mathrm{NH}_{4}^{+}$was determined by spectrophotometric method (APHA, 1998) using a UV-Visible spectrophotometer (UV-2450PC, Shimadzu). Concentrations of nitrate and nitrite were measured using a MIC ion chromatograph (Metohm, Switzerland). TOC of the resulting supernatant were measured using a Shimadzu TOC-5050A total carbon analyzer. The specific nitrification rate and TOC removal rate was determined from the time course of substrate disappearance.

\section{Results and discussion}

\subsection{Occurrence of heterotrophic nitrification in the Yangtze estuarine sediment}

To gain evidence on the occurrence of heterotrophic nitrification in the sediment, a selective inhibitor (acetylene) that affects autotrophic nitrifiers (Hynes and Knowles, 1982; Schimel et al., 1984; Dore and Karl, 1996; Bateman and Baggs, 2005) was used to evaluate the importance of heterotrophic nitrification in the nitrification in Yangtze estuarine sediment. The specific nitrification rate of the $\mathrm{S}-1$ sediment decreased from $0.27 \pm 0.03 \mathrm{mg} \mathrm{N} \mathrm{g}^{-1} \mathrm{MLSS} \mathrm{h}^{-1}$ to $0.07 \pm 0.02 \mathrm{mg} \mathrm{N} \mathrm{g}^{-1} \mathrm{MLSS}^{-1}$ when acetylene was added (Table 2). The specific nitrification rate of the $\mathrm{S}-2$ sediment decreased from $0.20 \pm 0.04 \mathrm{mg} \mathrm{N} \mathrm{g}^{-1}$ MLSS $^{-1}$ to $0.04 \pm 0.02 \mathrm{mg} \mathrm{N}$ $\mathrm{g}^{-1} \mathrm{MLSS}^{-1}$ when acetylene was added. The specific nitrification rate in the selective autotrophic nitrification inhibition treatment is about $25 \%$ of that in the control without autotrophic nitrification inhibition, suggesting that heterotrophic nitrification, in addition to autotrophic nitrification, is an important nitrification process in sediment. Many studies have shown the occurrence of heterotrophic nitrification in various environments where the organic carbon content is relatively high (Schimel et al., 1984; Pedersen et al., 1999; Islam et al., 2007).

\subsection{Bacterial population of autotrophic and heterotrophic nitrifiers in the Yangtze estuarine sediment}

To gain direct evidence that not only autotrophic nitrifiers but also heterotrophic nitrifiers were participating in the nitrification process in the sediment, heterotrophic and autotrophic nitrifier populations in the sediment was monitored. Both heterotrophic nitrification bacteria and autotrophic bacteria were detected in the sediment, confirming that both heterotrophic and autotrophic bacteria evolved into the nitrification process (Table 3). In the S-1 sediment, the number of heterotrophic nitrification bacteria was $7.1 \times 10^{7} \mathrm{MPN}^{-1}$ in sediment while that of autotrophic

Table 2

Effect of autotrophic nitrification inhibitor (acetylene) on the specific nitrification rate of Yangtze estuarine sediment.

\begin{tabular}{|c|c|c|}
\hline Yangtze estuarine sediment & $\begin{array}{l}\text { Nitrification rate without autotrophic nitrification inhibitor } \\
\left(\mathrm{mg} \mathrm{N} \mathrm{g}^{-1} \mathrm{MLSS}^{-1}\right)\end{array}$ & $\begin{array}{l}\text { Nitrification rate with autotrophic nitrification inhibitor } \\
\left(\mathrm{mg} \mathrm{N} \mathrm{g}^{-1} \mathrm{MLSS} \mathrm{h}^{-1}\right)\end{array}$ \\
\hline Sterile controls & nd & nd \\
\hline Site $1(S-1)$ & $0.27 \pm 0.03$ & $0.07 \pm 0.02$ \\
\hline Site 2 (S-2) & $0.20 \pm 0.04$ & $0.04 \pm 0.02$ \\
\hline
\end{tabular}


Table 3

Populations of heterotrophic and autotrophic nitrifiers in Yangtze estuarine sediment.

\begin{tabular}{lll}
\hline Yangtze estuarine sediment & $\begin{array}{l}\text { Heterotrophic nitrification bacteria } \\
\left(\mathrm{MPN} \mathrm{g}^{-1} \mathrm{MLSS}\right)\end{array}$ & $\begin{array}{l}\text { Autotrophic nitrification bacteria } \\
\left(\mathrm{MPN} \mathrm{g} \mathrm{MLSS}^{-1}\right.\end{array}$ \\
\hline Sterile controls & nd & nd \\
Site 1 (S-1) & $7.1 \times 10^{7}$ & $4.2 \times 10^{8}$ \\
Site 2 (S-2) & $3.3 \times 10^{7}$ & $2.8 \times 10^{8}$ \\
\hline
\end{tabular}

nd refers to not detected.

nitrification bacteria was $4.2 \times 10^{8} \mathrm{MPN} \mathrm{g}^{-1}$. In the S- 2 sediment, the number of heterotrophic nitrification bacteria was $3.3 \times 10^{7}$ $\mathrm{MPN} \mathrm{g}^{-1}$ in sediment while that of autotrophic nitrification bacteria was $2.8 \times 10^{8} \mathrm{MPN} \mathrm{g}^{-1}$. The presence of heterotrophic nitrifiers subsequently leads to the increase in the contribution of heterotrophic bacteria on the nitrification in the Yangtze estuarine sediment.

\subsection{Effect of organic carbon concentration on the heterotrophic and autotrophic nitrification}

The specific nitrification rate ranges from $0.69 \pm 0.05 \mathrm{mg} \mathrm{N} \mathrm{g}^{-1}$ MLSS $\mathrm{h}^{-1}$ to $1.02 \pm 0.06 \mathrm{mg} \mathrm{N} \mathrm{g}^{-1}$ MLSS $^{-1}$ in the sediment, showing the high tolerance of the nitrification process to organic carbon in the sediment (Fig. 2). Nitrification may be severely inhibited by the co-presence of organic carbon because the nitrification process is usually catalyzed by autotrophic bacteria (Strauss and Lamberti, 2000). For this reason, autotrophic nitrification rate sharply decreased when the initial TOC concentration increased from $0 \mathrm{mg} \mathrm{L}^{-1}$ to $160 \mathrm{mg} \mathrm{L}^{-1}$. However, heterotrophic nitrification was enhanced by the increase in organic carbon concentration. The specific heterotrophic nitrification rates increased from $0.01 \pm 0.00$ to $0.09 \pm 0.01 \mathrm{mg} \mathrm{N} \mathrm{g}^{-1}$ MLSS $^{-1}$ when the organic carbon concentration increased from 0 to $120 \mathrm{mg} \mathrm{L}^{-1}$, while those of autotrophic nitrification decreased from $0.20 \pm 0.01$ to $0.14 \pm 0.01 \mathrm{mg} \mathrm{N}$ $\mathrm{g}^{-1} \mathrm{MLSS} \mathrm{h}^{-1}$. The increase of heterotrophic nitrification can offset the decrease in autotrophic nitrification, which subsequently leads to the high tolerance of nitrification to the organic carbon. The

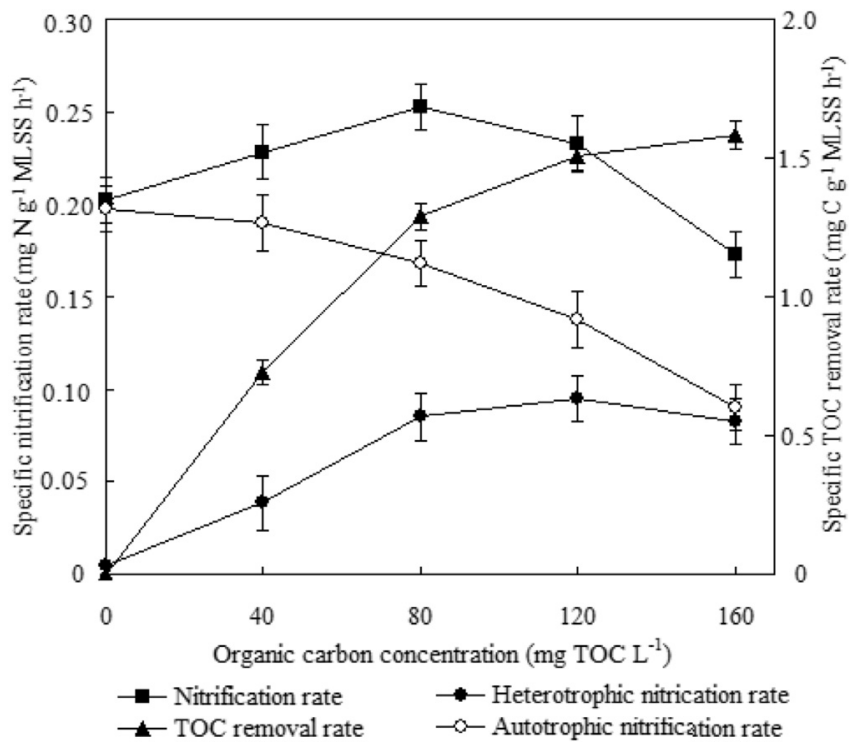

Fig. 2. Effect of organic carbon concentration on the nitrification, and the removal of organic carbon in Yangtze estuarine sediment. Sediment was collected from site 1 (S1). Initial concentration of $\mathrm{NH}_{4}^{+}-\mathrm{N}$ was $40 \mathrm{mg} \mathrm{L}^{-1}$ and organic carbon (glucose) was added at $0,40,80,120$, and $160 \mathrm{mg}$ TOC $\mathrm{L}^{-1}$. specific nitrification rates increased from $0.20 \pm 0.02$ to $0.25 \pm 0.02 \mathrm{mg} \mathrm{N} \mathrm{g}^{-1} \mathrm{MLSS} \mathrm{h}^{-1}$ when the organic carbon concentration increased from 0 to $80 \mathrm{mg} \mathrm{L}^{-1}$. The oxidation of organic carbon can provide energy and carbon for the heterotrophic nitrifiers (Schimel et al., 1984; Pedersen et al., 1999; Joo et al., 2005; Kim et al., 2005), which subsequently promotes the oxidation of ammonium in the Yangtze estuarine sediment.

The specific TOC removal rates increased from 0 to $1.6 \pm 0.06 \mathrm{mg} \mathrm{C} \mathrm{g}^{-1}$ MLSS $^{-1}$ when the organic carbon concentration increased from 0 to $160 \mathrm{mg} \mathrm{L}^{-1}$. The increase in organic carbon loading leads to the increase in organic carbon removal, which subsequently enhances the heterotrophic nitrification. It must be pointed out that heterotrophic nitrification is also inhibited when organic carbon concentration is relatively high $\left(>120 \mathrm{mg} \mathrm{L}^{-1}\right)$. The increased organic carbon can compete with ammonium for oxygen, which subsequently leads to the substrate inhibition of heterotrophic nitrification by organic carbon.

\subsection{Isolation of heterophic nitrifiers from Yangtze estuarine sediment}

Isolation of heterotrophic nitrification bacteria was performed to gain direct evidence on the engagement of heterotrophic nitrifiers in the nitrification process in the sediment. In this experiment, strain YIC-JL1 and UT10 with relatively strong heterotrophic nitrification ability were subsequently isolated. Most of the organic carbon and ammonium (>96.0\%) was simultaneously removed within $80 \mathrm{~h}$, demonstrating the occurrence of heterotrophic nitrification in strain YIC-JL1 and strain UT10 (Fig. 3). The 16S rDNA of strain YIC-JL1 has high similarity (>99.5\%) with that of many heterotrophic strains in the genus Serratia while that of strain UT10 has high similarity (>99.5\%) with that of heterotrophic strain in the genus Bacillus. In previous study, both Serratia and Bacillus with high heterotrophic nitrifying ability were isolated from soil or membrane bioreactor sludge (Kim et al., 2005; Lu et al., 2008, 2014). The successful isolation of heterotrophic nitrifiers from the Yangtze estuarine sediment further confirms the wide engagement of heterotrophic bacteria in the nitrification process in various environments.

The results of the molecular analysis experiments also show the difference between the isolated heterotrophic nitrifiers and common autotrophic nitrifiers. Culture independent molecular tools based on 16S rDNA have been developed to characterize the autotrophic ammonia-oxidizing bacteria from different environments and high similarities of partial 16S rDNA sequences of autotrophic ammonia oxidizers have been observed (Voytek and Ward, 1995; Stephen et al., 1996; Bothe et al., 2000). Based on this, the polygenetic analysis was performed to understand the relationship between isolated heterotrophic nitrifiers and the typical autotrophic nitrifiers. The commonly recognized genera of bacteria that carry out autotrophic nitrification are Nitrosomonas, Nitrosovibrio, Nitrosolobus, Nitrosospira, and Nitrobacter (Rittmann and McCarty, 2001). The results show that the isolated nitrifier from Yangtze estuarine sediment has no affiliation with any of the autotrophic nitrifiers (Fig. 4). Their closely related strains are 

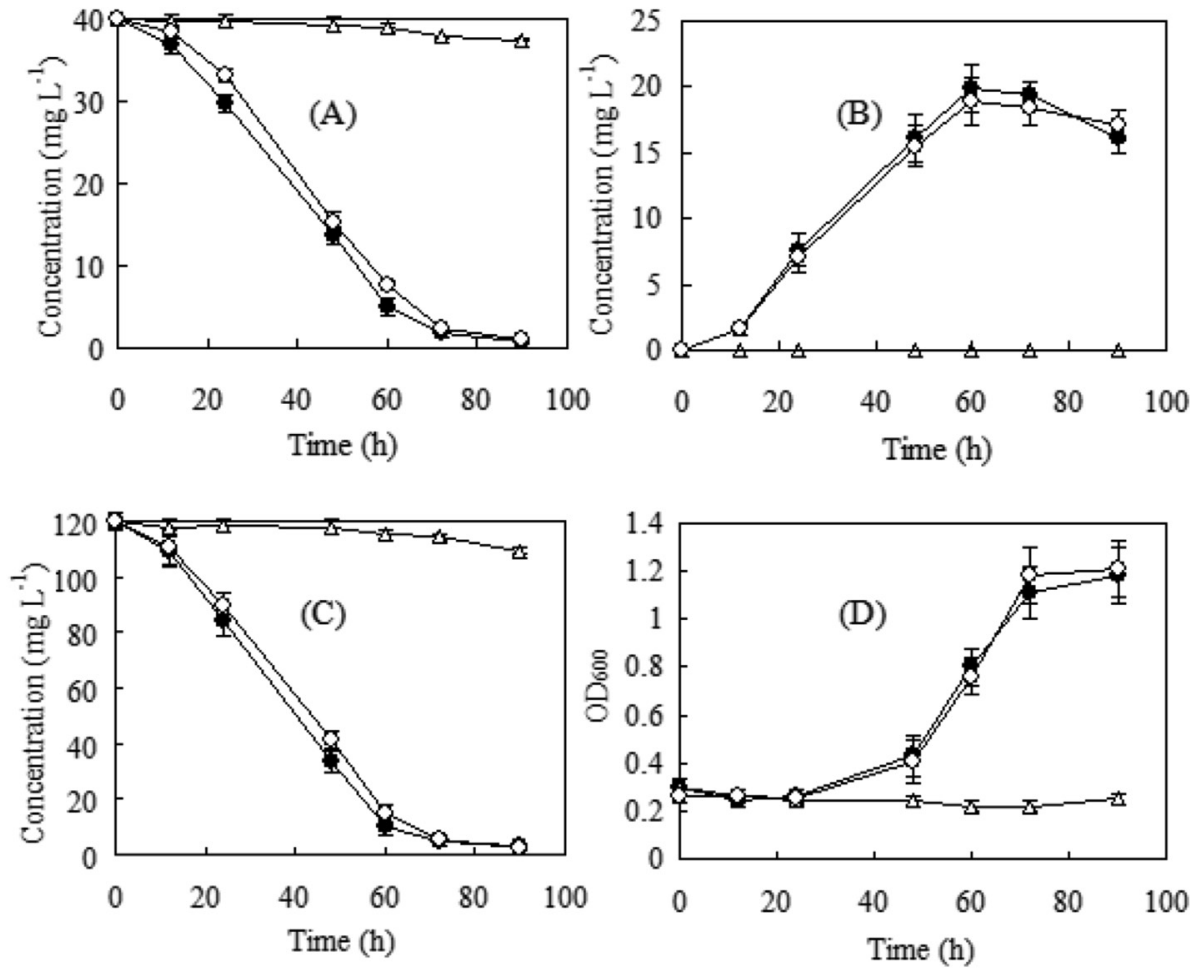

$\rightarrow$ Strain YIC-JL1 $\rightarrow$-Strain UT10 $\rightarrow$-Sterile control

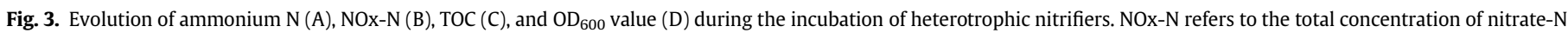
and nitrite-N.

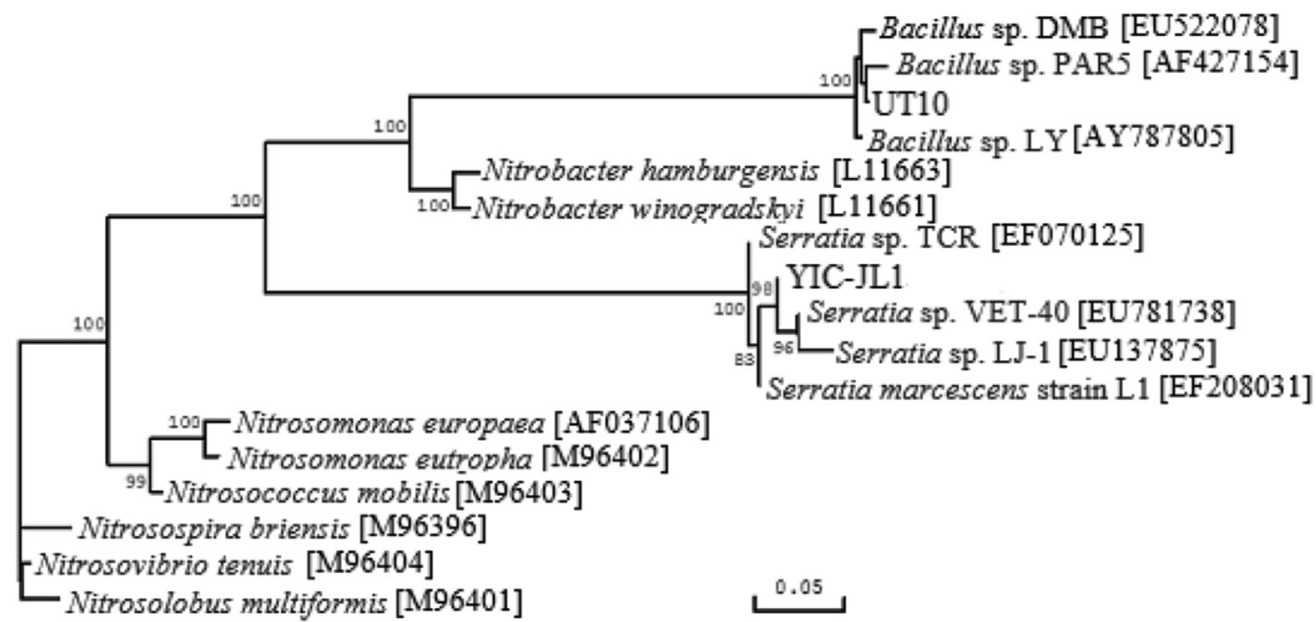

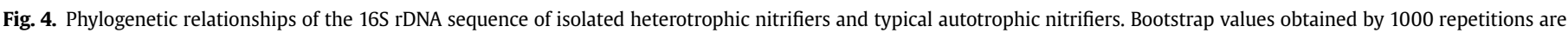
indicated as percentages at all branches.

known as heterotrophic bacteria. These results confirm the engagement of heterotrophs, in addition to autotrophs, in the nitrification in the Yangtze estuarine sediment.

\section{Conclusions}

This study demonstrates the engagement of heterotrophic nitrifiers in nitrification in the Yangtze estuarine sediment. Nitrification in the sediment was catalyzed by both autotrophic and heterotrophic nitrifiers. High nitrification rates can be maintained at high organic carbon level due to functional redundancy in nitrification in the Yangtze estuarine sediment. The increase of heterotrophic nitrification can offset the decrease in autotrophic nitrification, which subsequently leads to the high tolerance of nitrification to organic carbon. Since organic carbon usually coexists with ammonium, these findings have significant environmental implications in terms of the simultaneous removal of these contaminants in estuarine sediment.

\section{Acknowledgements}

This work was supported by One Hundred-Talent Plan of 
Chinese Academy of Sciences (Grant numbers of Y629041021 and Y610061033), National Natural Science Foundation of China (No. 41671319), the Two-Hundred Talents Plan of Yantai, and Research Program of CAS Key Laboratory of Coastal Environmental Processes and Ecological Remediation (No. 1189010002). The authors would like to thank the reviewers for their valuable suggestions and comments on the manuscript.

\section{References}

Alexander, M., Clark, F.E., 1965. Nitrifying bacteria. In: Black, C.A. (Ed.), Methods of Soil Analysis, Part 2. American Society of Agronomy, Madison, WI, pp. $1477-1483$

Altschul, S.F., Madden, T.L., Schäffer, A.A., Zhang, J., Zhang, Z., Miller, W., Lipman, D.J., 1997. Gapped BLAST and PSI-BLAST: a new generation of protein database search programs. Nucleic Acids Res. 25, 3389-3402.

American Public Health Association (APAH), 1998. Standard Methods for the Examination of Water and Wastewater, twentieth ed., Vol. 20. APHA, Washington, DC.

Bateman, E.J., Baggs, E.M., 2005. Contributions of nitrification and denitrification to $\mathrm{N}_{2} \mathrm{O}$ emissions from soils at different water-filled pore space. Biol. Fertil. Soils 41, 379-388.

Bernhard, A.E., Bollmann, A., 2010. Estuarine nitrifiers: new players, patterns and processes. Estuar. Coast. Shelf Sci. 88 (1), 1-11.

Bock, E., Koops, H.P., Harms, H., 1986. Cell Biology of Nitrifying Bacteria. Nitrification Spec Publ Soc Gen Microbiol, Vol. 20. IRL Press, Oxford, pp. 17-38.

Bothe, H., Jost, G., Schloter, M., Ward, B.B., Witzel, K., 2000. Molecular analysis of ammonia oxidation and denitrification in natural environments. FEMS Microbiol. Rev. 24, 673-690.

Devereux, R., Willis, S.G., 1995. Amplification of ribosomal RNA sequences. In: Akkermans, A.D.L., et al. (Eds.), Molecular Microbial Ecology Manua. Kluwer Academic Publishers, The Netherlands, 3.3.1-3.3.11. ISBN 0-7923-3698-4.

Dore, J.E., Karl, D.M., 1996. Nitrification in the euphotic zone as a source for nitrite, nitrate, and nitrous oxide at station ALOHA. Limnol. Oceanogr. 41, 1619-1628.

Elizondo-Patrone, C., Hernández, K., Yannicelli, B., Olsen, L.M., Molina, V., 2015. The response of nitrifying microbial assemblages to ammonium $\left(\mathrm{NH}_{4}^{+}\right)$enrichment from salmon farm activities in a northern Chilean Fjord. Estuar. Coast. Shelf Sci. 166 (Part A), 131-142.

Hou, L.J., Liu, M., Carini, S.A., Garder, W.S., 2012. Transformation and fate of nitrate near the sediment-water interface of Copano Bay. Cont. Shelf Res. 35, 86-94.

Hynes, R.K., Knowles, R., 1982. Effect of acetylene on autotrophic and heterotrophic nitrification. Can. J. Microbiol. 28, 334-340.

Islam, A., Chen, D., White, R.E., 2007. Developing a technique to quantify heterotrophic and autotrophic nitrification in acidic pasture soils. Commun. Soil Sci. Plant Anal. 38, 2309-2321.

Joo, H.S., Hirai, M., Shoda, M., 2005. Characteristics of ammonium removal by heterotrophic nitrification-aerobic denitrification by Alcaligenes faecalis No.4. J. Biosci. Bioeng. 100, 184-191.

Juliastuti, S.R., Baeyens, J., Creemers, C., 2003. Inhibition of nitrification by heavy metals and organic compounds: the ISO 9509 test. Environ. Eng. Sci. 20, 79-90.

Keeney, D.R., Nelson, D.W., 1982. Nitrogen-inorganic forms. In: Page, A.L. (Ed.), Methods of Soil Analysis, second ed. ASA-SSSA, Madison, WI, pp. 643-698. Agronomy No. 9.
Kim, J.K., Park, K.J., Cho, K.S., Nam, S.W., Park, T.J., Bajpai, R., 2005. Aerobic nitrification-denitrification by heterotrophic Bacillus strains. Bioresour. Technol. 96 1897-1906.

Lin, X., Hou, L., Liu, M., Li, X., Yin, G., Zheng, Y., Deng, F., 2016. Gross nitrogen mineralization in surface sediments of the Yangtze estuary. PLoS One 11 (3) e0151930. http://dx.doi.org/10.1371/journal.pone.0151930.

Lu, J., Jin, Q., He, Y., Wu, J., Zhao, J., 2008. Biodegradation of nonylphenol ethoxylates by Bacillus sp. LY capable of heterotrophic nitrification. FEMS Microbiol. Lett. $280,28-33$.

Lu, J., Jin, Q., He, Y., He, X., Zhao, J., 2014. Simultaneous removal of phenol and ammonium using Serratia sp. LJ-1 capable of heterotrophic nitrification-aerobic denitrification. Water Air Soil Pollut. 225, 2125-2135.

Miller, M.E., Cooney, J.J., 1994. Effects of tri-, di- and monobutyltin on heterotrophic nitrifying bacteria from surficial estuarine sediments. Arch. Environ. Contam. Toxicol. 27 (4), 501-506.

Papen, H., von Berg, R. 1998. A Most Probable Number method (MPN) for the estimation of cell numbers of heterotrophic nitrifying bacteria in soil. Plant Soil 199, 123-130.

Pedersen, H., Dunkin, K.A., Firestone, M.K., 1999. The relative importance of autotrophic and heterotrophic nitrification in a conifer forest soil as measured by ${ }^{15} \mathrm{~N}$ tracer and pool dilution techniques. Biogeochemistry 44, 135-150.

Rittmann, B.E., McCarty, P.L., 2001. Environmental Biotechnology: Principles and Applications, second ed. McGraw-Hill, New York.

Schimel, J.P., Firestone, M.K., Killham, K.S., 1984. Identification of heterotrophic nitrification in a sierran forest soil. Appl. Environ. Microbiol. 48, 802-806.

Somsamak, P., Cowan, R., Häggblom, M.M., 2001. Anaerobic biotransformation of fuel oxygenates under sulfate-reducing conditions. FEMS Microbiol. Ecol. 37 259-264.

Stephen, J.R., McCaig, A.E., Smith, Z., Prosser, J.I., Embley, T.M., 1996. Molecular diversity of soil and marine $16 \mathrm{~S}$ rRNA gene sequences related to beta-subgroup ammonia-oxidizing bacteria. Appl. Environ. Microbiol. 62, 4147-4154.

Strauss, E.A., Lamberti, G.A., 2000. Regulation of nitrification in aquatic sediments by organic carbon. Limnol. Oceanogr. 45 (8), 1854-1859.

Thompson, J.D., Gibson, T.J., Plewniak, F., Jeanmougin, F., Higgins, D.G., 1997. The clustal X windows interface: flexible strategies for multiple sequence alignment aided by quality analysis tools. Nucleic Acids Res. 24, 4876-4882.

Vetterli, A., Hyytiäinen, K., Ahjos, M., Auvinen, P., Paulin, L., Hietanen, S. Leskinen, E., 2015. Seasonal patterns of bacterial communities in the coastal brackish sediments of the Gulf of Finland, Baltic Sea. Estuar. Coast. Shelf Sci. 165 86-96.

Voytek, M.A., Ward, B.B., 1995. Detection of ammonium-oxidizing bacteria of the beta-subclass of the class Proteobacteria in aquatic samples with the PCR. Appl. Environ. Microbiol. 61, 1444-1450.

Wang, B., 2006. Cultural eutrophication in the changjiang (Yangtze River) plume: history and perspective. Estuar. Coast. Shelf Sci. 69 (3-4), 471-477.

Wheeler, D.L., Church, D.M., Lash, A.E., Leipe, D.D., Madden, T.L., Pontius, J.U. Schuler, G.D., Schriml, L.M., Tatusova, T.A., Wagner, L., Rapp, B.A., 2001. Database resources of the national center for Biotechnology Information. Nucleic Acids Res. 29, 11-16.

Xu, H., Wolanski, E., Chen, Z., 2013. Suspended particulate matter affects the nutrient budget of turbid estuaries: modification of the LOICZ model and application to the Yangtze Estuary. Estuar. Coast. Shelf Sci. 127, 59-62.

Xu, H., Newton, A., Wolanski, E., Chen, Z., 2015. The fate of phosphorus in the Yangtze (Changjiang) Estuary, China, under multi-stressors: hindsight and forecast. Estuar. Coast. Shelf Sci. 163 (Part B), 1-6. 